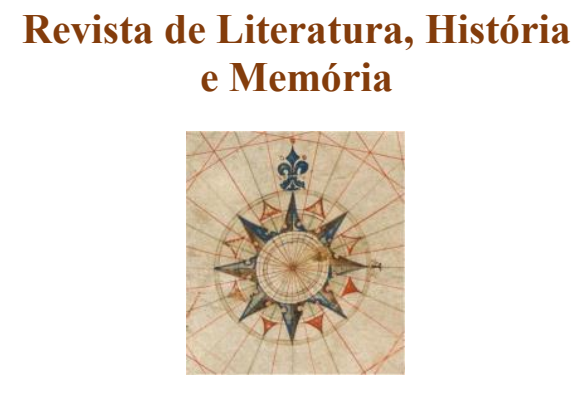

Seção: Pesquisa em Letras no contexto Latino-americano e Literatura, Ensino e Cultura

ISSN 1983-1498

VOL. 16 - No 28 - 2020

U N I O E S T E / CA S C A V E L - p. 273-289

\section{LOBATO NO SERTÃO DE JECAS E MONJOLOS}

Lobato in the hinterlands of jecas and monjolos

Gustavo Krieger Vazquez ${ }^{1}$
RESUMO: Analisaremos o conto "A vingança da peroba", de Monteiro Lobato, publicado em revista em 1916, e no livro Urupês, em 1918, posicionando-o na evolução literária percorrida pelo autor. Fazendo jus ao título anterior que Lobato queria dar ao livro - "Dez mortes trágicas" - temos um terrível acidente na casa de uma das personagens, Nunes, um fidedigno Jeca Tatu: um monjolo construído por ele acaba por matar, de forma brutal, seu filho. Por trás de toda ambientação rural e do humor negro, há uma construção narrativa que indica a obsessão do homem pelos seus bens materiais. Finalizaremos comparando a versão estabelecida do conto com seu texto original de 1916, o que lançará mais luzes sobre certas questões da obra.

ABSTRACT: In this article we will analyze the short story "A vingança da peroba", by Monteiro Lobato, published in a magazine in 1916 and in the book Urupês in 1918, placing it within the author's literary evolution. Living up to the previous title that Lobato wanted to give to the book - "Ten tragic deaths" - we have a terrible accident in the family of Nunes, a true Jeca Tatu: the monjolo he built ends up brutally killing his son. Behind all rural settings and black humor, there is a narrative construction that emphasizes man's obsession with his material goods. We will conclude by comparing the established version of the story with its original 1916 text, which will shed more light on some points previously dealt with.

KEYWORDS: Monteiro Lobato; Regionalism; Jeca Tatu; Urupês.

\title{
INTRODUÇÃO
}

Marisa Lajolo, em seu artigo "Jeca Tatu em três tempos", baliza a carreira de Lobato com três obras fundamentais. A primeira, "Urupês", de 1914, indicaria uma ideologia negativa em relação ao caboclo. A segunda fase seria marcada principalmente por "Jeca Tatuzinho", de 1924, quando questões sanitárias passaram a ser vistas por Lobato como causa dos problemas e limitações sofridos pelo homem do interior. A terceira é representada por "Zé Brasil", de 1947, quando a política entra em cena.

Observando com mais detalhamento esse itinerário, veremos como o conto "A vingança da peroba" se insere na primeira fase definida por Lajolo. Porém, mesmo dentro de um período encontramos mudanças e uma progressão. $\mathrm{O}$ conto representa um modo de

1 Graduado em Filosofia (UFPR), mestrando em Literatura (UFPR). 
Lobato enxergar o homem do interior que se foi alterando e aprofundando ao longo dos anos, parte de uma busca em se tratar fidedignamente o sertão, descrevendo sua ambientação e personagens de maneira verossímil. Isso também permitiu uma visão mais ampla do sertanejo, o que viria a desembocar na obra que iniciaria, ao nosso ver, a segunda fase: Problema vital.

\section{OS PRIMEIROS ANOS}

É de 1900 o primeiro conto publicado de Lobato situado no interior do país: "Noite de São João". Ambientado em uma vila rural durante as comemorações de tal festa, e não nos ermos, como seria frequente depois, à parte a qualidade do autor, é uma história que tende ao curioso, a um sertão engraçado e até mesmo inofensivo. De fato, após descrever o cenário uma fogueira, crianças correndo, bombinhas sendo explodidas, fandangueiros, gritos - o narrador resume: "De cada lado, cenazinhas pitorescas dividem a atenção" (LOBATO, 2014, p. 216).

Mas é nessa mesma época que encontramos uma prova de que a questão do caboclo já estava na mente do autor desde os primórdios de sua carreira. No conto "Café! Café!", também de 1900, sobre um major que é obcecado pela monocultura a ponto de tornar-se insano por isso, temos o narrador caracterizando a personagem da seguinte forma:

Na cabeça já branca habitavam ideias de pedra. Como essas famílias de caboclos que vegetam ao pé dos morros numa choça de palha, cercada de taquara, com um terreirinho, moenda e o chiqueiro e toda a imensidade azul e verde das serras e dos céus a insulá-las da civilização, assim a cabeça do major. (LOBATO, 2014, p. 315-316).

Se há uma característica comum a esses primeiros contos regionalistas é que o sertão de Lobato encaminhava todos que lá estavam a uma vida simples e com pouca variedade; um reflexo daquilo que ele sentia pessoalmente. Em 1905, após deixar a capital e se mudar para Taubaté, o escritor diz em uma carta para seu amigo e também escritor Godofredo Rangel: "Meu processo de burrificação marcha firme. Este ar, esta coisa chamada "interior", arrasa uma criatura em poucos meses. (...) As ideias vêm-me lorpas, com o carimbo local, ideias de boticário da roça." (LOBATO, 2010, p. 88).

As limitações que o autor enxergava no sertão como fonte de inspiração literária também foram confessadas em 1907: "Parece-me erro supor que o artista cria independente do meio. Meio pífio, artista pífio - obra de arte pífia (...) Os que ficam no interior só dão de si água panada (...) E, no entanto, nós temos talento, Rangel - sentimos isso, não?" (LOBATO, 
2010, p. 155). Apesar de estar escrevendo contos regionalistas por anos, é como se Lobato ainda não houvesse encontrado no sertão algo a ser contado que equivalesse, em qualidade, às intenções que carregava como escritor. De fato, preocupava-se com a aproximação entre seu trabalho artístico e suas vivências, essencial para que fosse possível a criação de algo com qualidade. Citando um poema de Camões ${ }^{2}$ para Rangel, Lobato explica:

Pegamos toda a técnica do escrever e educamos o nosso senso de observação - mas vivemos embolorados dentro de caixas. (...) Mas que assuntos, que temas, podem existir dentro de caixas? (...) Os artistas subjetivos que só tiram de si em vez de tirar do mundo que os rodeia, ficam introspectivos em excesso e acabam satisfazendo a um público muito restrito: a si mesmos. (LOBATO, 2010, p. 182-183).

Os anos passaram e seu desconforto por estar vivendo em pequenas vilas gerou espécies de crônicas amalgamadas com contos que se passariam em Itaoca, "uma grande família com presunção de cidade" (LOBATO, 2014, p. 202), ou na vila de Oblivion. Em "A vida em Oblivion", de 1908, além do relato sobre como é viver no "esquecimento", há uma crítica direta a Bernardo Guimarães:

Lê-lo é ir para o mato, para a roça - mas uma roça adjetivada por menina de Sion, onde os prados são amenos, os vergéis floridos, os rios caudalosos, as matas viridentes, os píncaros altíssimos, os sabiás sonorosos, as rolinhas meigas. Bernardo descreve a natureza como um cego que ouvisse contar e reproduzisse as paisagens com os qualificativos surrados do mau contador. Não existe nele o vinco enérgico da impressão pessoal. Vinte vergéis que descreva são vinte perfeitas e invariáveis amenidades. Nossas desajeitadíssimas caipiras são sempre lindas morenas cor de jambo.

Bernardo falsifica o nosso mato. Onde toda a gente vê carrapatos, pernilongos, espinhos, Bernardo aponta doçuras, insetos maviosos, flores olentes. Bernardo mente. (LOBATO, 2014, p. 197).

Acreditamos que Lobato começou a enxergar, atrás de um aparente "meio pífio" que havia embaçado sua visão inicial, um mundo bruto, difícil e, por que não, real; e seria esse mundo que viria a ser representado em seus mais importantes contos regionalistas.

Mas não ainda. Surgiriam antes os contos "Júri na roça", de 1909, e "Pedro Pichorra", de 1910. Aqui, ainda temos muito do pitoresco, embora a veia crítica do escritor comece a despontar. Ainda não tão mordaz quanto seria alguns anos depois, Lobato já dá leves cutucadas no homem sertanejo, criticando suas crendices e falta de pragmatismo.

Seja nas cartas ou nos contos, é evidente que a inquietação por não estar conseguindo

2"Não se aprende, senhor, na fantasia,/Sonhando, imaginando ou estudando,/Senão vendo, tratando e pelejando." 
dar vazão à sua criatividade e talento aumentava, o que culminou na fase mais criativa e conhecida de sua carreira como contista. Em 1911, após o falecimento de seu avô, Lobato herda a fazenda São José, em Buquira, município próximo a Taubaté. Final do ano, muda-se para lá, onde passa a tratar da manutenção e produção do local. E não demora para que uma ideia ressurja em sua mente. Meses depois da mudança, em uma carta, eis o broto daquela semente lançada anos antes, em "Café! Café!": "Já te expus a minha teoria do caboclo, como o piolho da terra, o Porrigo decalvans das terras virgens? Ando a pensar em coisas com base nessa teoria, um livro profundamente nacional, sem laivos nem sequer remotos de qualquer influência europeia" (LOBATO, 2010, p. 264).

\section{"VELHA PRAGA" E "URUPÊS"}

Dito e feito. "Velha Praga" é um artigo, escrito em 1914, para a seção de "Queixas e reclamações" do jornal O Estado de São Paulo, ${ }^{3}$ que possui pouca estrutura ficcional no que tange ao enredo: é um manifesto de revolta contra o caboclo. Partindo da questão das queimadas feitas por caipiras para limpar terrenos, Lobato fala sobre esse homem preguiçoso, que pouco ou nada produz, destruindo as matas nativas por indolência e ignorância, sem se preocupar com coisa alguma senão os objetivos mais simples e imediatos. Árvores milenares viram cinzas, para que o caboclo plante "na terra em cinzas um bocado de milho, feijão e arroz" (LOBATO, 2014, p. 168). Sua família o espelha, tendo uma prole numerosa e com os mesmos defeitos; mesmo um filho, criança de sete anos, imita o pai, mantendo um pito na boca e uma faca na cintura.

É em "Velha praga" que encontramos não só esse tipo e a localização onde muitos de seus contos se desenvolverão - os ermos do sertão - mas onde há o sutil batismo de uma de suas mais famosas personagens: o Jeca Tatu. Perdido entre outros nomes genéricos - Manoel Peroba, Chico Marimbondo, “ou outros sons ignaros” (LOBATO, 2014, p. 168) -, surge o Jeca.

Um mês depois, o Jeca retornaria em "Urupês", outro artigo de jornal. A miscigenação dos índios com os "quatrocentos de Gedeão", que chegaram ao Brasil junto de Tomé de Sousa, gerou uma nova raça que "existe a vegetar de cócoras, incapaz de evolução, impenetrável ao progresso" (LOBATO, 2014, p. 171). As gerações passam, proclama-se a Independência, a escravidão é abolida, funda-se a República, e o caboclo segue de cócoras,

3 Mas que acabou sendo publicado em seção de mais visibilidade, em 12/11/1914 (terceira página). 
indiferente a tudo. Ele sobrevive seguindo a lei do menor esforço: come as frutas que caem das árvores, vive em uma casa miserável, não possui sentimento de pátria, sua medicina se resume a rezas e simpatias, e sua arte é um decisivo "nada". O texto termina com um funesto "só ele, no meio de tanta vida, não vive" (p. 180).

Seria difícil pensarmos em modos de criticar ainda mais o caboclo, com Lobato usando um grande léxico para incriminá-lo e ofendê-lo. Embora isso seja um jugo pesado, mesmo nessa obra temos uma breve indicação do que ocorreria em suas obras posteriores isto é, o caboclo Jeca Tatu não representaria todos os habitantes do sertão. Sim, havia muitos sertanejos trabalhadores: ao lado da simplicidade e ignorância do Jeca, contrasta "a opulência de um seu vizinho e compadre que 'está muito bem"' (LOBATO, 2014, p. 175).

Apesar da importância de ambos artigos, eles fazem parte de uma trajetória com ainda alguma distância a ser percorrida. Conforme colocado por Sylvia Leite (1996, p.78), "o limite maior que se constata nesse momento do pensamento lobatiano é o restringir-se à apresentação dos problemas, sem uma reflexão mais detida sobre suas causas e motivações profundas, o que parcialmente será superado num momento posterior." - momento esse do qual fazem parte não só futuros textos políticos, mas seus contos.

\section{ADENTRANDO O SERTÃO}

Se em "Velha praga" e "Urupês" temos uma crítica em relação ao caboclo sem a utilização da estrutura de enredo própria do conto - e com um fazendeiro olhando para as ações do sertanejo nas proximidades, mas ainda com distanciamento, não tendo deixado o seu próprio espaço social - passamos a ter, em contos subsequentes de Lobato, mudanças importantes: primeiramente, somos colocados em uma estrutura ficcional. Em segundo lugar, há um narrador/personagem que, deixando sua fazenda/cidade para trás, adentra o sertão sobre o seu cavalo e passa a observar esse mundo de perto, ouvindo e analisando o que os sertanejos têm a dizer. Esses contos abrangem questões mais complexas do que os escritos anteriormente por Lobato: lidam com traições, mortes brutais, apatia, fim de linhagens familiares, abandono; isto é, estão distantes do mero pitoresco. Encontramos neles os "carrapatos, pernilongos, espinhos" dos quais Lobato sentia falta em Bernardo Guimarães.

O primeiro desses contos é “O mata-pau”, de $1915,{ }^{4}$ em que um filho adotado acaba

4 As datas utilizadas são as de Contos completos, de 2014. Grande parte delas está nas mais diversas edições das obras, mesmo desde Urupês, outros contos e coisas, a chamada "Edição Onibus" da década de 1940, quando Lobato ainda estava vivo (o livro contém, além de Urupês, os outros livros adultos de Lobato). Outras foram 
por causar a desgraça de uma família. Um trecho dele nos indica as dificuldades vistas em retratar fidedignamente o sertão. O narrador, acompanhado de um capataz, vê um sítio abandonado; curioso, pergunta como isso ocorreu:

O camarada contou a história que para aqui traslado com a possível fidelidade. O melhor dela evaporou-se, a frescura, o correntio, a ingenuidade de um caso narrado por quem nunca aprendeu a colocação de pronomes e por isso mesmo narra melhor que quantos por aí sorvem literaturas inteiras, e gramáticas, na ânsia de adquirir o estilo. (LOBATO, 2014, p. 118).

Temos o narrador/personagem admitindo sua distância, como homem culto, do homem sertanejo sobre o qual ele deseja falar. Em contos futuros, essa distância foi sendo encurtada: se em "O mata-pau" o narrador ouve a situação de alguém que não estava implicado nos eventos ocorridos, em "Bucólica" e "A colcha de retalhos", ambos também de 1915, se de um lado o narrador ainda é um homem da cidade que está de passagem pelo sertão, por outro ele passa a ouvir os relatos daqueles que estiveram diretamente envolvidos nos eventos narrados: no primeiro, da agregada da família onde ocorreu um desastre - a menina de quem ela cuidava morreu de sede por descaso dos pais; no segundo, de uma velha senhora - cada parte de uma colcha de retalhos que ela costurou ao longo dos anos simbolizava uma época da vida de sua neta, que acabou por fugir.

\section{"A VINGANÇA DA PEROBA"}

A evolução se completa em "A vingança da peroba". ${ }^{5}$ No conto, o narrador sobre o cavalo sai de cena: não há nenhum homem letrado interagindo com os caipiras, ou mesmo algum coadjuvante citadino; as personagens são todas caipiras.

O conto fala sobre Nunes, um sertanejo que é um Jeca puro: vive em uma casa miserável, quase uma tapera; para tomar uma decisão, gasta uma semana pitando, coçando a cabeça, observando o vazio; seu filho, Pernambi, seguindo o pai, também usa faca de ponta à cinta, de pito à boca; ambos também são muito afeitos ao álcool.

Apesar de viver no ócio, de uma maneira lastimável, a inveja que sente de seu vizinho

sendo adicionadas em edições posteriores. Embora as datas de alguns contos variem - por exemplo, na edição de 1946 da "Onibus", "Os faroleiros" consta como sendo de 1915; porém, na edição de Urupês da ed. Globo, da década de 2000, está 1917; em Contos completos, de 2014, está sem data - dos contos que nos interessam de perto, elas se mantiveram constantes ao longo das edições, além de serem coerentes com as cartas do autor.

5 Além da questão do ano da escrita que tratamos anteriormente, notamos que a publicação dos contos ocorreu em outra sequência, indicada na dissertação de Milena Martins (1998, p. 35). "A vingança da peroba", um dos últimos contos de Urupês a serem escritos, foi o primeiro deles a ser lançado na Revista do Brasil. 
de terras, Pedro Porunga - um exemplo daquele vizinho bem-sucedido mencionado em "Urupês" -, faz Nunes, em certo momento, decidir plantar milho; posteriormente, constrói seu próprio monjolo para moer o milho, visto que Pedro era famoso monjoleiro. A desavença entre os dois remonta a uma paca de estimação de Nunes, morta e cozida pela família Porunga; para se vingar, Nunes decide derrubar uma peroba que servia de divisão de terreno dos dois sertanejos.

Para transformar a peroba em monjolo, Nunes chama um amigo maneta, o Teixeirinha, e ambos fazem um serviço medíocre. O pilão mais desperdiça milho do que mói, e assim nosso protagonista se torna uma piada nas redondezas. Em um dia de ócio, Nunes dá de beber a seu filho, algo até então rotineiro; dessa vez, porém, o garoto, ébrio, segue até o monjolo, cai dentro dele e tem a cabeça esmagada. No fim do texto, tomado pela raiva, Nunes destrói com suas próprias mãos o maquinário.

Vendo com mais detalhes, o conto se mostra bastante rico pela maneira como engaja o leitor. De início, Lobato utiliza uma técnica para aumentar a surpresa do desfecho trágico: a primeira frase indica que "a cidade duvidará do caso" (LOBATO, 2014, p. 69), sem especificar qual ele é. Havíamos notado que nesse conto não aparece o homem urbano adentrando o sertão e encontrando seus moradores - há apenas os caipiras, sem visitantes. Mas os contos de Lobato foram publicados e comercializados nas capitais e cidades grandes, para serem lidos por homens urbanos letrados. Com essa única frase inicial, Lobato indica que o conto foi feito para essas pessoas. Além disso, aguça o interesse delas: o evento ocorrido nos ermos é algo que precisa ser lido para ser crido. Foi a forma buscada para ligar os mundos rural e urbano, o que antes era feito com o citadino a cavalo apresentando todo o enquadramento geográfico conforme adentra o interior, como em "Colcha de retalhos" ou "O mata-pau", por exemplo. Aqui, Lobato começa o enredo de forma mais direta.

$\mathrm{Na}$ segunda frase do conto, somos informados de que Nunes havia sido "durante meses o palhaço da zona" (LOBATO, 2014, p. 69). Vendo a personagem principal sob essa ótica, esperamos um situação cômica; sendo o desastre final o que ele é, essa frase nos despista do caminho que a história tomará, ao mesmo tempo em que acentua o humor negro presente.

Uma outra indicação do trágico desfecho ocorre no meio do conto, quando descobrimos que o maneta Teixeirinha é um contador de causos - de fato, o trabalho dele e de Nunes para fabricar o monjolo é de uma inaptidão incrível, com eles conversando e bebendo constantemente, em vez de focarem no serviço. Um dos causos contados é sobre árvores que teriam se vingado das pessoas que as derrubaram, sempre de uma maneira trágica. 
Novamente, Lobato lança uma isca para o fim, agora indicando de onde provirá a desgraça. (Embora isso esteja no título, notamos que na primeira edição de Urupês a obra se chamava "Chóóó! Pan!", o que mantinha o mistério; porém, posteriormente retornou a ser "A vingança da peroba".)

\section{MACHISMO?}

Um ponto que pode chamar a atenção (principalmente nos dias de hoje) é um suposto machismo presente na obra. Em certo momento, o narrador nos diz que Nunes teria decaído por causa de "muita cachaça na cabeça e muita saia em casa". Pedro Porunga, ao contrário, é pai de vários filhos homens, e o narrador indica que a fazenda dele "era natural que prosperasse, com tanta gente no eito" (LOBATO, 2014, p. 70). Uma leitura rápida poderia indicar misoginia da parte de Lobato; porém, lendo o texto com atenção, vemos que o fato de possuir tantas filhas mulheres é um problema para a personagem e, inclusive, para aquela sociedade, em que as mulheres não se ocupavam de certas tarefas, mas não uma posição do autor em relação ao mundo. O próprio Nunes não é um homem trabalhador rodeado por inúteis - ele mesmo pouco trabalha. Além disso, é agressivo e injusto com sua família, não suportando as mulheres da casa; bêbado, ameaça afogá-las na lagoa. Como o narrador descreve por meio de um cachorro, Brinquinho, naquele lugar era cada um por si - que cada um cuidasse de seus bernes e caçasse seus preás (p. 71).

Nunes sente afeto apenas por Pernambi, e o garoto o imita também no maltrato para com as mulheres, que ofende física e verbalmente. Temos aqui outra ferramenta narrativa: primeiramente, exacerbando o amor do protagonista pelo menino, em contrapartida ao seu desprezo pelas mulheres, Lobato aumenta a tragédia final. Em segundo lugar, há a ironia do autor: as opiniões de Nunes sobre os gêneros (ou sobre qualquer outra coisa) não têm credibilidade. De fato, o narrador chega a dizer, em determinado momento, que "Nunes não sabia coisa alguma, tirante emborcar o gargalo e difamar os Porungas" (LOBATO, 2014, p. 75). O que nos é apresentado é a situação em uma família disfuncional comandada por um inepto, não um julgamento generalizado sobre gêneros.

Ao mesmo tempo, a mulher de Nunes é uma das poucas personagens do conto com bom senso. Conforme o marido idealiza e cumpre seus planos malfadados, temos nela a representação do ceticismo racional, o que o narrador descreve tanto em seus gestos e feições (após ouvir sobre os planos de uma plantação, "a mulher repuxou os lábios num muxoxo de dúvida"), como pelas suas falas ("Monjolo? Ché, qu'esperança!" (LOBATO, 2014, p. 71)). Os 
ímpetos de Nunes? A culpa pela morte da criança? Contratar um maneta para fazer a máquina? É pela voz dela que o leitor pode ver refletida a sua própria descrença - e a do autor. De fato, "se a mulher emudecia, emudecia com ela a razão" (p. 73).

O modo como Nunes lida com sua esposa (e com outras personagens antagonistas) também merece atenção. Nos momentos de menos controle, ele a espanca: ao ver que o monjolo foi mal construído por Teixeirinha (o que ele não havia notado, trabalhando ao lado dele), ele bate na mulher e a xinga, como se ela fosse o próprio amigo maneta: "encarnando na esposa o odiado maneta deslombou-a numa sova de consertar negro ladrão" (LOBATO, 2014, p. 78). Por outro lado, no final do conto, ao ver que o monjolo causou a morte de seu filho, o espanca e ofende como se a um ser humano: "Chegou teu dia, desgraçado! (...) toma Barbazu! (...) rebenta, demônio (...) estoura, feiticeiro do diabo!" (p. 81-82). Fato é que sua capacidade de comunicação é, para dizer o mínimo, faltosa. Mesmo nos momentos em que há algum controle por parte dele isto é apresentado pela negação ao diálogo: quando Nunes não deseja responder ou discutir com sua família ou com Pedro Porunga sobre os atos que deseja fazer, ele reduz sua fala a um sonoro "bééé", finalizando qualquer conversa (p. 72-73).

Em suma, Lobato criou um caipira ignorante, machista, alcoólatra, casado com uma mulher racional que sofre injustamente; mas não deixou de lado sua veia irônica de escritor.

\section{O QUE SE POSSUI}

Uma das questões mais importantes desse conto, em nossa opinião, é algo que o coloca além do regionalismo, de cenas interioranas, por lidar com um tema moderno. No coração de "A vingança da peroba" está o fatídico monjolo; na verdade, este não apenas é o centro e final da trama, mas um dos conectores sociais entre as personagens. O que as une entre si são os objetos que elas possuem ou fabricam. Esses objetos criam, mantém e encerram as relações sociais.

Vejamos como o duradouro conflito entre Nunes e os Porungas iniciou: a morte de uma paca de estimação? Não, isso não importou - "até aí nada" (LOBATO, 2014, p. 69), nos diz o narrador, numa frase-parágrafo, recurso que Lobato utiliza em seus contos, para dar ênfase. O que causou a desavença foi os Porungas não terem dividido a carne morta com o legítimo dono, para que ele pudesse comê-la. Importa mais a paca como um produto de consumo do que como um ser vivo.

Falando com seu filho, Nunes resume a relação entre o que a pessoa é e o que ela possui: "homem que não bebe, não pita, não tem faca de ponta, não é homem" (LOBATO, 
2014, p. 70). A garrafa de bebida, o cigarro, a faca: isto é, os objetos materiais que são possuídos e consumidos são mais que importantes, são fundamentais, são eles que definem o que a pessoa é e não é.

A disputa entre Nunes e Pedro permanece sem mais desdobramentos, até o primeiro descobrir que Pedro é dono de uma "besta arreada", o que faz Nunes sentir dor "no fundo da alma" (LOBATO, 2014, p. 71). A inveja por seu adversário possuir algo valioso faz com que o caipira decida plantar, construir um monjolo... isto é, também possuir coisas. De fato, Nunes não entende muito de monjolos, ou mesmo de como fabricar um. Seu rival, no entanto, é famoso enquanto monjoleiro; isto é, ele é alguém que possui esse aparato e sabe lidar com ele. Para "vencê-lo", Nunes precisaria ter o mesmo aparato.

Para compensar a paca não comida, Nunes retira uma árvore que servia de divisão de terras com o vizinho, para fazer o monjolo, sabendo que assim o estava agredindo - metade da árvore deveria ser dele. A humanização dessa árvore está no próprio título - ela se "vinga". Havíamos também falado dos causos contados por Teixeirinha. Apesar do caráter lúdico e folclórico deles, o fato é que eles contam que pedaços de madeira, buscando a vingança, agem como se fossem seres dotados de razão.

Por falar em Teixeirinha: grande amigo, companheiro de bebidas, até Nunes descobrir que o monjolo foi mal construído. Então, o amigo se torna "excomungado do diabo de maldelazento de maneta..." (LOBATO, 2014, p. 78). A pessoa é o que ela produz.

Não basta possuir algo, é importante que o oponente saiba disso. Assim que o monjolo está pronto, ao invés de inspecioná-lo adequadamente, Nunes solta fogos de artifícios em direção à fazenda do rival. Mais que isso: agora que tem a máquina, Nunes pode gritar: "Conheceu, porungada choca, quem é João Nunes Eusébio da Ponta Alta?" (LOBATO, 2014, p. 77). Uma pessoa é conhecida pelo que ela tem.

Em seguida, Pedro Porunga se dirige ao sítio de Nunes, aparentemente para pedir a paz, o que seria uma atitude magnânima. Mas não. Na verdade, essa é uma desculpa para ver o monjolo e poder criticar o vizinho pela obra malfeita. Toda a visão que os Porungas e outros moradores da região passam a ter de Nunes é através do monjolo - no final das contas, era como ele queria ser visto: pela sua produção, mas certamente não esperava que fosse de maneira tão negativa.

A bebedeira que causou a desgraça na família de Nunes ocorreu por ele descobrir que um conhecido colocou em uma égua o nome de Ronqueira, o apelido do monjolo malfeito isto é, o animal seria tão ruim quanto o monjolo, outra aproximação entre um ser vivo e um objeto. Sendo Nunes alguém reconhecido através do monjolo, há ainda, por tabela, a 
aproximação entre um animal e um ser humano.

Após a morte do filho, Nunes destrói o monjolo com as próprias mãos, como se batesse em um homem, dirigindo-se diretamente ao aparato e falando: "chegou teu dia, desgraçado!" (LOBATO, 2014, p. 81).

Em suma, os objetos são tratados como pessoas, as pessoas são medidas pelos objetos que possuem e fabricam, e muitas vezes a vida em si nada vale, seja a paca tendo mais valor morta do que viva, ou as filhas de Nunes, desprezadas por não produzirem.

No final, duas imagens instigantes para nos trazerem de volta à humanidade. Enquanto Nunes destrói o monjolo, o narrador nos diz que estava ocorrendo "o duelo trágico da demência contra a matéria bruta" (LOBATO, 2014, p. 82). Mesmo uma mente perturbada, demente como estava a de Nunes, ainda é humana, o que difere definitivamente seu possuidor de um objeto inerte, uma matéria bruta.

E em uma imagem simbolizando a razão humana contra os objetos, Nunes busca encontrar no fundo de uma máquina a cabeça do filho. Mas ela não está lá.

\section{DUAS VERSÕES DO CONTO}

Cotejando a versão de "A vingança da peroba" que foi lançada na Revista do Brasil, em 1916, com a que se estabeleceu a partir das Obras completas (usamos a paginação do recente Contos completos da Biblioteca Azul), temos várias mudanças pequenas e algumas mudanças maiores. Vejamos alguns exemplos. Eles não são exaustivos, mas nos concentramos naqueles que reforçam ideias aqui apresentadas anteriormente.

Como exemplo das pequenas alterações existentes, mas que não modificam o texto de forma significativa, temos o primeiro parágrafo:

\begin{tabular}{|l|l|}
\hline \multicolumn{1}{|c|}{1916} & \multicolumn{1}{|c|}{ Contos completos } \\
\hline $\begin{array}{r}\text { A cidade duvidará do caso. Não obstante, } \\
\text { aquelle monjolo do Dito Nunes, no Varjão, foi } \\
\text { durante mezes o palhaço da zona. No bairro da }\end{array}$ & $\begin{array}{l}\text { A cidade duvidará do caso. Não obstante, } \\
\text { aquele monjolo de João Nunes no Varjão foi } \\
\text { durante meses o palhaço da zona. Sobretudo no } \\
\text { Porungada, sobretudo, onde assistia Pedro } \\
\text { bairro dos Porungas, onde assistia Pedro }\end{array}$ \\
$\begin{array}{l}\text { Porunga, mestre monjoleiro de bem soada fama, } \\
\text { fungavam-se á conta das trapalhices do engenho } \\
\text { risos sem fim. (p. 281). }\end{array}$ & $\begin{array}{l}\text { Porunga, mestre monjoleiro de larga fama, } \\
\text { fungavam-se à conta do engenho risos sem fim. } \\
\text { (p. 69). }\end{array}$ \\
\hline
\end{tabular}

Muitos parágrafos curtos da versão de 1916 foram unidos em apenas um, ou desmembrados em outros. Vale mencionar um trecho: 


\begin{tabular}{|c|c|}
\hline 1916 & Contos completos \\
\hline $\begin{array}{l}\text { Ambos sitiantes em terras próprias, } \\
\text { convizinhavam separados pelo espigão do } \\
\text { Nheco, e por uma certa malquerença provinda } \\
\text { de uma certa caçada. } \\
\text { Nunes corria uma paca, num domingo, e a } \\
\text { bicha, dobrando o morro, dá de frente com um } \\
\text { filho do Porunga casualmente a lenhar por alli. } \\
\text { Zás! uma foiçada na volta da pá deu com ella } \\
\text { em terra. Até ahi nada. Mas comeu-a, sem ao } \\
\text { menos mandar de presente um quarto ao } \\
\text { legitimo dono. Isto foi aggravo. (p. 282). }\end{array}$ & $\begin{array}{l}\text { Sitiantes ambos em terras próprias, } \\
\text { convizinhavam separados pelo espigão do Nheco } \\
\text { - e por malquerença antiga. Levantara Nunes } \\
\text { uma paca, certo domingo; mas ao dobrar o morro } \\
\text { a bicha esbarrou de frente com um Porunguinha } \\
\text { que casualmente lenhava por ali. Zás! Certeiro } \\
\text { golpe de foice dá com ela em terra. } \\
\text { Até aí nada. } \\
\text { Mas comeram-na, sem ao menos mandarem um } \\
\text { quarto de presente ao legítimo dono. Legítimo, } \\
\text { sim, porque, afinal de contas, aquela paca era } \\
\text { uma paca de nomeada. (p. } 69) \text {. }\end{array}$ \\
\hline
\end{tabular}

Lobato decidiu colocar "Até aí nada" em seu próprio parágrafo, para enfatizá-lo, conforme havíamos comentado antes. Nota-se que, na versão original, apenas o filho de Pedro Porunga que estava a cortar lenha comeu a paca.

Ocorre, ocasionalmente, adição ou remoção de alguma frase (abaixo, em itálico):

\begin{tabular}{|c|c|}
\hline 1916 & Contos completos \\
\hline $\begin{array}{l}\text { A sua casa, de esteios roliços e portas de } \\
\text { embau'ba rachada, muito encardida de picumam, } \\
\text { prenunciava tapera próxima. } \\
\text { As paredes, de tão rachadinho o barro, dir-se- } \\
\text { iam praguejadas duma legião de lagartixas } \\
\text { immoveis. } \\
\text { Porco nenhum. Gallinhada escassa. Ao cachorro } \\
\text { Brinquinho não lhe valia ser mestre paqueiro de } \\
\text { nomeada, andava de barriga ás costas, com bernes } \\
\text { no toitiço. (p. } 283-284) \text {. }\end{array}$ & $\begin{array}{l}\text { Sua casa, de esteios com casca e portas de } \\
\text { imbaúba rachada, muito encardida de picumã, } \\
\text { prenunciava tapera próxima. } \\
\text { Capado, nenhum. Galinhada escassa. } \\
\text { Ao cachorro Brinquinho não lhe valia ser mestre } \\
\text { paqueiro de fama; andava de barriga às costas, } \\
\text { com bernes no toitiço. (p. 71). }\end{array}$ \\
\hline $\begin{array}{l}\text { Mas era compadre e acabou-se. } \\
\text { Nunes passou mais uma semana em trabalhos } \\
\text { de 'maginação. }\end{array}$ & $\begin{array}{l}\text { Mas era compadre e acabou-se. "Bééé!" } \\
\text { Uma nova semana passou Nunes em trabalhos } \\
\text { de "maginação". }\end{array}$ \\
\hline
\end{tabular}

No primeiro exemplo, a pobreza da casa é ressaltada, o que Lobato talvez tenha considerado um excesso. No segundo, ele repete o recurso utilizado por Nunes para evitar discussões. A repetição vai marcando a personagem, tornando-a cada vez mais caricata.

Apresentamos uma diferença que chama a atenção pelo inesperado; é o final do conto:

\begin{tabular}{|c|c|}
\hline 1916 & Contos completos \\
\hline $\begin{array}{c}\text { Por fim, do monjolo maldito, só restava uma } \\
\text { tranqueira escavada de peças em desmantelo. O }\end{array}$ & $\begin{array}{c}\text { Por fim, quando o monjolo maldito era já um } \\
\text { monte escavacado de peças em desmantelo, o }\end{array}$ \\
\hline
\end{tabular}




\begin{tabular}{|l|l|}
\hline \multicolumn{1}{|c|}{1916} & \multicolumn{1}{|c|}{ Contos completos } \\
\hline $\begin{array}{l}\text { caboclo exhausto, caiu ao lado della, a arquejar, } \\
\text { abraçado ao corpo de Pernambi. E a sua mãe, } \\
\text { tremula, remexia o fundo do pilão tentando } \\
\text { apanhar a cabecinha que faltava. (p. 295). }\end{array}$ & $\begin{array}{l}\text { mísero caboclo tombou por terra, arquejante, } \\
\text { abraçado ao corpo inerte do filho. } \\
\text { Instintivamente sua mão trêmula apalpava o } \\
\text { fundo do pilão em procura da cabecinha que } \\
\text { faltava. (p. 82). }\end{array}$ \\
\hline
\end{tabular}

"Mãe" ao invés de "mão" foi um erro tipográfico. Em uma carta a seu irmão, Lobato (1959, p. 151) explica: "Diga ao Heitor [cunhado] que quando ler uma história de monjolos na Revista do Brasil, onde diz mãe, no final, leia mão. A revisão faz a gente dizer asneiras grossas, como essa - e tira o gosto de escrever para jornais." Porém, é um erro interessantíssimo; a imagem é não só curiosa mas até coerente: o desespero materno assim descrito carrega enorme tristeza.

Nota-se que na versão estabelecida temos um texto corrido. Porém, na versão de 1916 há duas pausas. A primeira, indicada por um traço longo, é antes de Porunga visitar Nunes e ver o trabalho malfeito (LOBATO, 1916, p. 291). A segunda é apenas uma linha em branco, antes da sequência de eventos que leva à morte do filho de Nunes (p. 293). Elas estão bem colocadas, e são coerentes, espaçando eventos temporalmente distantes. Quanto à questão posterior de suprimi-las, é provável que Lobato tenha preferido um texto sem pausas, para ganhar dinamismo.

Essa busca por um ritmo menos truncado fica evidente nas diferenças maiores encontradas entre os textos. Há trechos removidos que serviam como ajuda para o leitor citadino entender o interior. Primeiro, a epígrafe: um trecho de "Vinte horas de liteira", de Camilo Castelo Branco, presente em 1916, mas removida posteriormente. Temos o narrador da epígrafe dizendo que "Nas cidades é que já não há sentimento de originalidade nenhuma (...) Quando quero retemperar a imaginação gasta vou caldeal-a á incude [sic] do viver campesino", e termina pedindo: "Conta-me, pois, uma história sentimental, meu amigo". (LOBATO, 1916, p. 281) Disso, há uma ligação lógica com a abertura do conto, o "A cidade duvidará do caso. Não obstante (...)" (LOBATO, 2014, p. 69) que, como tratamos antes, é capaz de aproximar o leitor citadino da obra. Isso a epígrafe também fazia, mas a custo de ser um paratexto longo, além da repetição do intento.

Há outros trechos removidos que indicam a preocupação inicial de Lobato em ser compreendido pelo leitor citadino, o que, com o tempo, talvez ele tenha visto como sendo um excesso dispensável. Comecemos com um caso breve, aqui assinalado em itálico: 


\begin{tabular}{|c|c|}
\hline 1916 & Contos completos \\
\hline $\begin{array}{l}\text { Corria as roças, contente da vida, unhando os } \\
\text { caules polpudos em pleno arreganhamento da } \\
\text { dentuça vermelha - isso que a botanica } \\
\text { despoetisa chamando raizes adventicias ao } \\
\text { axophyto superior. Palpava as bonecas tenrinhas } \\
\text { a madeixarem-se duma cabellugem louro- } \\
\text { translucida. (p. 284). }\end{array}$ & $\begin{array}{l}\text { Visitava as roças muito contente da vida, } \\
\text { unhando os caules viçosos já em pleno } \\
\text { arreganhamento da dentuça vermelha, ou } \\
\text { apalpando as bonecas tenras, a madeixarem-se da } \\
\text { cabelugem louro-translúcida.(p. } 72 \text { ). }\end{array}$ \\
\hline
\end{tabular}

Enfim, uma explicação científica e linguística que não auxilia a narração dos eventos.

Há dois momentos longos que foram removidos, por desviarem o foco narrativo. Um deles ocorre entre a descrição das famílias sertanejas. Temos o seguinte, no texto estabelecido:

E cônscio de que já era homem, o piquirinha batia nas irmãs, cuspilhava de esguicho, dizia nomes à mãe, além de muitas outras coisas próprias de homem.

Do outro lado tudo corria pelo inverso. Comedido na pinga, Pedro Porunga casara com mulher sensata, que lhe dera seis "famílias", tudo homem. (LOBATO, 2014, p. 70).

Em 1916, entre os dois parágrafos há uma longa explicação de que uma mulher norteamericana (não nomeada) havia escrito em um livro sobre a criança caipira fumar e andar armada, o que a enchia de medo; de que um padre espanhol (também não nomeado) publicou um folhetim no Rio de Janeiro, criticando a descrição dela como sendo nociva ao país; e o narrador dizendo ser neutro nessa disputa: estaria apenas descrevendo o fato (LOBATO, 1916, p. 283). Algo muito temporal, que envelheceria rapidamente, caso tivesse sido mantido.

O segundo trecho longo removido é quando Pedro Porunga conta aos familiares sobre o monjolo malfeito de Nunes. O narrador diz que eles aumentavam cada vez mais as pilhérias e, quanto a Nunes, "enfeitavam-no como se faz ao mastro de são João. Sobre as linhas gerais debuxadas pelo velho, os Porunguinhas iam atando cada qual o seu buquê" (LOBATO, 2014, p. 79). Na primeira versão, entre uma frase e outra há um longo trecho - meia página explicando sobre esse mastro de são João, sem relação com o enredo senão como representação da cultura daqueles moradores do interior. Vejamos o início do texto, posteriormente suprimido:

Enfeitavam-no como se faz ao mastro de S. João. Já viram? O "pintador", mestre pedreiro ou "curioso", sempre um negro, chega e caia o pau nos encruzes. Depois, sob o olhar pasmado da assistência, mergulha um furabolos engenhoso no urucú e, de beiço pendurado pela alta concentração de espirito, vai roleteando o mastro de círculos vermelhos; depois, entre os 
círculos, desenha a dedo uma ordem de XX muito igualados; depois, uma de 00 verdes (...) (Lobato, 1916, p. 292).

Esses fragmentos removidos indicam uma preocupação inicial, quando da publicação na Revista do Brasil, com o mundo sertanejo parecer menos estranho e mais compreensível ao leitor. Porém, eles interrompiam o fluxo do texto com informações em excesso: assim, a ligação com o leitor urbano se resume, na versão estabelecida, apenas ao início do conto. Lobato preferiu um conto com dinamicidade e onde o sertão falasse mais por si, sem um narrador indicando com frequência suas opiniões e conhecimentos a respeito dele.

\section{CONCLUSÃO}

Neste estudo indicamos mudanças na forma como Lobato enxergava e retratava o sertão: de uma sociedade pitoresca, para uma de pessoas miseráveis e improdutivas, até chegar a uma que é competitiva e destrutiva. Se nos atentarmos às cartas que o autor de "Urupês" trocou, após a publicação desse artigo, com o amigo Godofredo Rangel, vemos que ele continuou alterando sua visão em relação ao caboclo: desde igualar todos os brasileiros ao Jeca, inclusive ele mesmo (03/07/1915); a criticar quem via o caboclo como sendo pitoresco e engraçado, sem compreender seus problemas (07/02/1916); a preferir os sertanejos aos habitantes da cidade (08/10/1916); e, após vender sua fazenda e mudar-se para São Paulo, confessar: "Virei a casaca. Estou convencido de que o Jeca Tatu é a única coisa que presta neste país" (08/12/1917) (LOBATO, 2010, p. 321, 343, 374-375 e 412, respectivamente).

Uma outra mostra dessa mudança ocorre no início de 1918, quando Lobato lança $O$ Saci-Pererê: resultado de um inquérito. No epílogo, o autor critica a valorização dada a culturas europeias, muitas vezes sem conexão alguma com a realidade do Brasil, em detrimento da nossa própria cultura, fato do qual o Saci é um representante. No final, eis que surge o Jeca:

Pobre do meu Jeca Tatu (...) Tu maculas com uma nota de originalidade a obra maravilhosa do plágio. (...) tu, Jeca, tens a suprema coragem de não ser grotesco por figurinos franceses. A verdade é esta: Jeca é a única afirmação de individualidade não laivada de ridicularias que possuímos. (LOBATO, 2008, p. 373).

Essa preocupação em relação ao Jeca, a valorização de suas particularidades, alcança no mesmo ano um novo patamar: os problemas do caboclo seriam fruto de sua péssima saúde, 
vítima que era de doenças que proliferavam graças à falta de atenção dos governantes. Esse tema, tratado em Problema Vital, está distante do suposto problema hereditário apresentado em "Urupês" - o caboclo ser "um dos quatrocentos de Gedeão trazidos por Tomé de Sousa num barco daqueles tempos" (LOBATO, 2014, p. 171). Com o tempo, como apontado por Lajolo (1983, p. 103), Lobato "parece ter corrigido progressivamente os desvios de uma má consciência" - e, nesse longo caminho, "A vingança da peroba" é parte fundamental.

Mais do que uma questão ética que Lobato buscou sanar, transformações ocorreram em sua época, alterando as relações econômicas entre o mundo rural e o urbano. Há mostras em "A vingança da peroba" de uma deterioração da vida rural tradicional. Se tomamos as ideias apresentadas por Antonio Candido em Parceiros do Rio Bonito (finalizado em 1954, publicado em 1964), seja a parte da tradição rural, seja os desequilíbrios causados pela urbanização, encontramos equivalentes nesse conto de Lobato. Nele há dois vizinhos que não compartilham nada, em que não há ajuda mútua, solidariedade alguma. Nem a paca de um, nem a árvore que está entre os seus terrenos é dividida entre eles; João Porunga tem conhecimento sobre monjolos que não divide com Pedro Nunes - prefere ver seu adversário fracassar. Certa ironia há, inclusive, na forma como Teixerinha é chamado de "compadre" (LOBATO, 2014, p. 72) - o que mais fazem é beber juntos. É uma distância considerável para uma sociedade em que, de acordo com explicação ouvida por Candido, de um sertanejo que conheceu, a partilha e a ajuda mútua são questões fundamentais: "no mutirão não há obrigação com as pessoas, e sim para com Deus, por amor de quem se serve ao próximo" (CANDIDO, 2017, p. 60). Temos, no conto de Lobato, uma sociedade que já não realiza a partilha, o compadrio, que compete entre si. Mas, ao mesmo tempo em que indica o fim de uma época, nos apresenta pessoas ambiciosas, produtoras de mercadorias.

De fato, questões levantadas por Lobato mantiveram-se presentes na literatura, tendo preocupado mais de um autor regionalista - por exemplo, em Jorge Amado, principalmente em suas primeiras obras, ou em Calunga, de Jorge de Lima - em que a vida de um homem é definida por aquilo que ele produz e os conflitos da sociedade capitalista estão em evidência. Vale mencionar também o conto "Um pobre homem", de Dyonélio Machado, que integra o livro homônimo de 1927. Ele conta com um enredo próximo ao de "A vingança da peroba": o protagonista, de tão atarefado que está em cuidar de uma máquina que colhe arroz, se esquece de sua filha que precisava de ajuda, e que acaba por falecer.

O que estudamos a respeito de Lobato e o Jeca - as transformações da visão do autor em relação ao sertanejo - coincide com transformações socioeconômicas que atravessaram o país ao longo das décadas, e faz parte de um estudo maior sendo preparado pelo autor deste 
artigo. Do início da República, passando pela Belle Époque, chegando à ditadura Vargas com crises e sucessos ocorrendo nesse tempo - temos não somente um país buscando se ajustar às suas dificuldades, mas também escritores preocupados com isso, dos quais Lobato faz parte de forma significativa. Assim, "A vingança da peroba" não é apenas uma progressão de um caminho iniciado muito antes por Lobato dentro do regionalismo; o conto também indica preocupações de seu tempo, que se tornariam recorrentes no futuro.

\section{REFERÊNCIAS}

CANDIDO, Antonio. Os parceiros do rio Bonito. 12. ed. Rio de Janeiro: Ouro sobre azul; São Paulo: Edusp. 2017.

LAJOLO, Marisa. "Jeca Tatu em três tempos". In: Schwarz, Roberto (org). Os pobres na literatura brasileira. São Paulo: Brasiliense, 1983.

LOBATO, Monteiro. "A vingança da peroba". In: Revista do Brasil. Ano I, v. I, n.3, março 1916, p. 281-295. Disponível em: <https://bibdig.biblioteca.unesp.br/handle/10/26228>. Acesso em 28/08/20.

Cartas escolhidas, $1^{\circ}$ tomo. São Paulo: Brasiliense, 1959.

. O Saci-Pererê: resultado de um inquérito. São Paulo: Globo, 2008.

A barca de Gleyre. São Paulo: Globo, 2010.

Contos completos. São Paulo: Biblioteca azul, 2014.

LEITE, Sylvia Helena Telarolli de Almeida. Chapéus de palha, panamás, plumas, cartolas: a caricatura na literatura paulista (1900-1920). São Paulo: UNESP, 1996.

MARTINS, Milena Ribeiro. Quem conta um conto ... aumenta diminui, modifica: o processo de escrita do conto lobatiano. Dissertação (Mestrado em Literatura). Campinas: Unicamp, 1998. 